\title{
Eurostudia
}

\section{The Use and Misuse of Information in Securitate's Files: The Case of Plamadeala}

\section{Cristina Plamadeala}

Volume 10, numéro 1, 2015

From Today's Observation Post: Collaboration and Resistance under Communism

Vues du poste d'observation du présent : collaboration et résistance sous le communisme

Kollaboration und Widerstand im Kommunismus - Betrachtungen aus heutiger Sicht

URI : https://id.erudit.org/iderudit/1033885ar

DOI : https://doi.org/10.7202/1033885ar

Aller au sommaire du numéro

Éditeur(s)

Le Centre canadien d'études allemandes et européennes

ISSN

1718-8946 (numérique)

Découvrir la revue

Citer cet article

Plamadeala, C. (2015). The Use and Misuse of Information in Securitate's Files: The Case of Plamadeala. Eurostudia, 10(1), 125-139.

https://doi.org/10.7202/1033885ar
Résumé de l'article

This short article discusses a series of Securitate documents which contain various inconsistencies, and which were written on or about the Romanian theologian Antonie Plamadeala. Examining these files, I attempt to reconstruct the case Securitate built against Plamadeala in the late 1940s, and point to errors and forgeries, which they may contain. Stated differently, I look at evidence, which may have been fabricated by Securitate in order to prove Plamadeala's alleged ties to the Legionary Movement. I do this by first laying out the series of accusations the Romanian secret police brought against Plamadeala in 1949 and the way in which it constructed its evidence to support its case against him. I then offer a succinct analysis of ways in which one may derive truth from the plethora of information such files may bring to the attention of the modern investigator, truth which, as this article shows, is often juxtaposed with untruth in Securitate archival records.
Tous droits réservés $@$ Le Centre canadien d'études allemandes et européennes, 2015
Ce document est protégé par la loi sur le droit d'auteur. L'utilisation des services d'Érudit (y compris la reproduction) est assujettie à sa politique d'utilisation que vous pouvez consulter en ligne.

https://apropos.erudit.org/fr/usagers/politique-dutilisation/ 


\title{
Cristina Plamadeala
}

Concordia University

\begin{abstract}
:
This short article discusses a series of Securitate documents which contain various inconsistencies, and which were written on or about the Romanian theologian Antonie Plamadeala. Examining these files, I attempt to reconstruct the case Securitate built against Plamadeala in the late 1940s, and point to errors and forgeries, which they may contain. Stated differently, I look at evidence, which may have been fabricated by Securitate in order to prove Plamadeala's alleged ties to the Legionary Movement. I do this by first laying out the series of accusations the Romanian secret police brought against Plamadeala in 1949 and the way in which it constructed its evidence to support its case against him. I then offer a succinct analysis of ways in which one may derive truth from the plethora of information such files may bring to the attention of the modern investigator, truth which, as this article shows, is often juxtaposed with untruth in Securitate archival records.
\end{abstract}

Despite the wide usage of secret police files as a means of promoting transitional justice, such documents are not necessarily always reliable to speak the "truth" (for example, Ursache 2013; Verdery 2014). As Lavinia Stan and Nadia Nedelsky put it, "files access's effectiveness as a tool of truth revelation depends on the authenticity, completeness, and reliability of the secret archives, none of which should be taken for granted" (Stan and Nedelsky 2013: 3). In this article I seek to elaborate further on this idea.

For that, I provide as example some of the Romanian communist secret police (Securitate) files pertaining to the Romanian theologian Antonie Plamadeala (1927-2005), a prominent figure of the Romanian society and Orthodox Church, who served as Metropolitan of Transylvania from 1982 until his death. In this article, I focus on his experience with the Romanian secret police 
until his release from the Jilava prison in 1956 and about the key events that lead to his prison discharge. To note, my concern with this topic is driven not only by my interest in Securitate's surveillance and arrest of civilians in Communist Romania, but also by my attempt to find out about the history of my own family, as Antonie Plamadeala was a distant relative of mine, namely, my great uncle.

As a theology student and later a monk (from 1949 onwards), ${ }^{1}$ Plamadeala was accused by Securitate of having being a member of the Legionary Movement, an extreme right organization that rose to power in 1940 together with General (and later Marshal) Ion Antonescu, following King Carol II's abdication. ${ }^{2}$ As a result of these allegations, Plamadeala was imprisoned at the Jilava ${ }^{3}$ and Galati ${ }^{4}$ penitentiaries from 1954 to 1956. His incarceration, however, came roughly five years after his initial 1949 trial during which he was tried in absentia. ${ }^{5}$ Beginning with 1948 until his arrest in 1954, the young Plamadeala was on a continuous run from the Securitate (Seuleanu et al 1999: 145). This article focuses primarily on his retrial, which Plamadeala requested shortly after his arrest. In the two years during which his second trial lasted (1954-1956), the evidence employed during his first trial proved to be most likely fabricated and the charges initially brought against him—his alleged membership in the Legionary Movement-dropped.

Described as "repositories of truth" (Verdery 2014: 72) after the fall of communism, the Securitate archives are often employed in the attempt to prove whether or not individuals were collaborators with extreme right or left parties. Taking the Securitate files on Antonie Plamadeala as a case study, I show why the usage of official documents produced by governmental institutions of the former Romanian Communist regime, although useful in uncovering the past, demands caution from those examining and interpreting them.

\footnotetext{
${ }^{1}$ In 1959, Plamadeala was excluded from the monastic life, as a result of the decree 410 from 11 October 1959. By then he was a doctoral student at the Faculty of Theology of the University of Bucharest. He remained unemployed until 1961, when he was given a position as an "unqualified worker" (muncitor necalificat) at a plant in Bucharest. He worked at this plant until 1968 (Aioanei 2013: 23-24).

${ }^{2}$ King Carol II abandoned his rights to the throne in order to marry Elena Lupescu, a divorcée (Stan and Turcescu 2007: 121).

${ }^{3}$ ACNSAS, fond penal, dossier 905, vol. 4: 2.

${ }^{4}$ ACNSAS, fond penal, dossier 905, vol. 4: 71.

${ }^{5}$ ACNSAS, PF, dossier 905, vol. 4: 2.
} 
In addition, it is important to highlight that the sources used here to construct my arguments are confined both in quantity and time frame (19481956), covering, needless to say, not all the archival data available on this theologian's life, but only some of the ones which were made available by the National Council for the Study of the Securitate Archives (ACNSAS) in May of 2014. It is possible that other archival sources do exist on this theologian, but which have not yet been open to the public. Therefore, the conclusions brought forth in this article are limited to information I could derive from the fond penal dossiers 905, vols. 1-10, which are currently stored at ACNSAS, located in Bucharest and Popesti Leordeni, Romania.

Looked at as a case study, the Securitate files regarding Plamadeala bring to light some insight into what may have constituted as evidence for Securitate personnel. In the first part of this article I offer a concise narrative of the story behind the accusations brought against Plamadeala, touching briefly on his 1949 trial, 1954 arrest and retrial; in the second part I list a series of examples of factual errors and forgeries I found in Plamadeala's Securitate dossiers, aiding to discredit the legitimacy and validity of these files. I conclude with recommendations pertaining to reading secret police files.

\section{The Case of Plamadeala: The Accusations}

Antonie Plamadeala, Leonida being his birth name prior to his becoming a monk in 1949, was born on 17 November 1926 in the village Stolniceni in Bessarabia (Aioanei 2013: 14-15), a region which at that time was part of the Romanian Kingdom, and which is now identified on the modern map as the Republic of Moldova. Prior to the commencement as well as during the Second World War, Plamadeala was a student at the Theological Seminary "Gabriil Banulescu Bodoni" in Bessarabia's capital city, Chisinau. Later, however, he studied at the Chisinau Pedagogical School, when the Seminary was closed as a result of Soviet Union's annexation of Bessarabia in 1940. In 1941, when Bessarabia was annexed by the Romanian Kingdom, Plamadeala reenrolled at the Theological Seminary in Chisinau. However, because of the Soviet invasion of Bessarabia in 1944, he and his family sought out refuge in Isalnita, a village next to the city of Craiova, in southern Romania. The following fall, he enrolled at the Seminar "Nifon 
Mitropolitul," in Bucharest, from which he graduated in 1945 (Buda and Maica Anastasia 2012: 235-236).

The young Plamadeala and his family left Bessarabia, with the hope of escaping its Soviet invasion, only months before the arrival of the Soviet troops in Bucharest on 31 August 1944. There, the Soviet Army faced a government open to collaborate with the Soviets in defeating the Germans. And, within only half a year, the Soviets established in Romania a government "to their liking"(Deletant 1995: 4), with Communists from Moscow and local supporters who once were either incarcerated for their adherence to Communist ideals or were working "underground" (Idem: 4) for the Communist cause.

The establishment of the Romanian People's Republic on 30 December 1947, under the guidance of Moscow, entailed radical transformations in Romania's internal and foreign affairs, with the country's internal political affairs, the economy, the judicial and education systems, as well as Romania's main religious denominations, with the Orthodox Church as the leading one, being targeted first. But to do so, a solidified political party, made of "Communist elite and dedicated membership" (Idem: 1) had to be put in place at the expense of eliminating political opposition (Idem: 1-5).

It is in this socio-political milieu that Plamadeala found himself in Bucharest of the late 1940s, while pursuing his undergraduate studies at the Faculty of Theology at the University of Bucharest. Those were years when major and abrupt transformations were occurring in the Romanian society, in the midst of a nation with a small minority of citizens who were not all yet fully discouraged or taken over by fear to revolt against these changes. Terror and countrywide arrests of the regime's opponents or "enemies of the state" were in the early stages. In 1948, there were still many, especially among the young Romanians, whose courage may have been still nurtured by the hope that they were capable to oppose these transformations and eventually bring about an auspicious end, with the support of America and its western allies.

Antonie Plamadeala, in a post-1989 interview provided to several Romanian journalists about his life, stated that he was one of those who joined the fight against Communism in those crucial years: 
I was among those who wanted to change the regime and was waiting for the Americans to come. I was told that they were coming on the $1^{\text {st }}$ or the $15^{\text {th }}$ of the month and they never came! And I was one of those who were betrayed by Churchill who lied about Yalta until his death! .... During this time propaganda was being carried out by a German radio station installed in Austria, that Europe will be free. I don't remember what it was called. It [the radio station] was preaching daily: "Romanian brothers, resist! If not on the $1^{\text {st }}$ [of the month], we are coming on the $15^{\text {th }}$ [of the month]. The American army is on the verge of departing to liberate you from Communism." Well, these repeated calls that were convincing, attracted us all, all of us who were refugees were also anticommunists; we ran away from the Russians. ... We began to organize ourselves, based on university departments, student dorms, to all make a resistance organization against Communism, so that Communism would enter [in the country] later or not enter at all (cited in Plamadeala and Petcu 2011: 52).

Student demonstrations were not the only anti-Communist activity in which Plamadeala engaged during this crucial period. He was also writing and distributing copies of an ultra-nationalist newspaper by the name of Ecoul Basarabiei (The Echo of Bessarabia). Years later, he explained his involvement with, and purpose of, this newspaper as attempt to fight for the "liberation of Bessarabia, for the Romanian Bessarabia, for the fact that this was temporary, that the Americans were coming, that we would return home, for not losing our hope and so on" (cited in Idem). Many of these newspaper copies managed to get to Securitate, the theologian confirmed: "When they arrested me, it was not hard for them to recognize based on the style and ideas, that one of those who were writing it was I" (cited in Idem). It is possible, therefore, that in the eyes of Securitate, Plamadeala's main crime may have been embodied by his association with the writing and distribution of this ultra-nationalist newspaper and with his involvement in the anti-communist resistance. Still, one must not exclude his probable mingling with the legionaries, as Securitate documents suggest, as an additional reason to make him a solid target of the secret police.

In a Securitate dossier dating from 1948 Plamadeala was listed along with the other twenty-nine students, ${ }^{6}$ from the Faculty of Theology and Veterinary

\footnotetext{
${ }^{6}$ The other twenty-nine students were: Sultana Petre, Bordasiu Nicolae, Vaman Constantin, Braga Roman, Brasov Nita, Vaduva Dumitru, Toader Petre, Pavel St. Ion, Chitu Vasile, Manciulescu Ion, Miclescu Feliciu, Vila Petre, Ionescu Aurelian, Popescu Dumitru, Munteanu Paul, Popescu I, Petre, Badescu Mihai, Stoenescu Constantin, Popescu N-Gheorghe-Ogratin, Nistor Constantin, Tudor Constantin, Serban Gheorghe, Balea Traian-Nerva, Brandus Vasile, Clinciu Gheorghe, Macarei Dionisie, Stroe Ion, Caltea
} 
School of the University of Bucharest, as pending arrest orders for alleged ties to the fascist Iron Guard or Legionary Movement. But, unlike most of these students, Plamadeala was arrested six years after he was first brought to Securitate's attention. The conclusions brought forth at the end of his second trial (1956) bring to one's awareness Securitate's inconsistencies in building a case against him in 1949. Whereas he was accused of Legionarism in 1949, for which he was given seven years in prison and five years of "civic degradation," the original charge was dropped in 1956. Instead, he was reconvicted for "conspiracy against the social order" when evidence collected by Securitate in support of its accusation of Plamadeala's ties to the Legionary organization proved to be unwarranted. $^{8}$

\section{The Construction of Evidence by Securitate and their "Cross-examination"}

The first series of factual errors concerning Plamadeala's Securitate files pertain to the very case built against him in support of his arrest in 1954. As I have mentioned above, Plamadeala was tried in absentia in 1949, and accused of being a member of the notorious Fascist Legionary Movement. ${ }^{9}$ In a Securitate dossier dating from 1948, Plamadeala was listed as pending arrest orders for alleged ties to the fascist Iron Guard or Legionary Movement. ${ }^{10}$ After countless interrogations of the arrested students, Securitate issued on December 8 of that year a comprehensive police report, which brought into light its own conclusions, recommending that these young men be tried by a Military Tribunal. These students, including Plamadeala, were accused of engaging "in a conspiring

Corneliu and Cusa I. George. The list of students was finalized on 14 January 1949. ACNSAS, fond penal, dossier 905, vol. 2: 2.

${ }^{7}$ ACNSAS, fond penal, dossier 905, vol. 2, 12: 87.

${ }^{8}$ ACNSAS, fond penal, dossier 905, vol. 4: 181.

${ }^{9}$ ACNSAS, fond penal, dossier 905, vol. 2: 2.

${ }^{10}$ The terms "Iron Guard" and the "Legionary movement" (or "the Legion") are often employed interchangeably to refer to the Romanian nationalistic organization, anti-Semitic, and anti-Communist in rhetoric and activity, which was founded in 1927 by Corneliu Zelea Codreanu (Shapiro 2007: 136-137; Atkin, Biddis and Tallett 2011: 211). Initially, this organization was called the Legion of the Archangel Michael (Atkin, Biddis and Tallett 2011: 82-83) and was built on the efforts of ultra-nationalist Romanian youth aiming to combine "Christian mysticism with a cult of death" (Fischel 1998: 73) in order to remove the Jewish population from the country's economic and political affairs. 
manner to challenge the existent order and to destroy the accomplishments of the established democracy." ${ }^{11}$ They were described as

those who in the past encouraged and committed the most odious of crimes against the Romanian people, having had brought about the Fascist-Hitlerist occupation in the country and that has pushed us to an unjust war against the USSR. ... Inside the country [the Legionary Movement] practiced the most fanatic and chauvinist type of nationalism-promoting enmity against the established democratic regime and being unhappy about our country obtaining its national independence. ${ }^{12}$

These students' arrests, as Securitate documents reveal, were most likely triggered by its finding of several copies of the Legionary manifesto entitled "Christian brothers" (Frati crestini) sometimes in May 1948 in Olt county. ${ }^{13}$ According to student declarations retrieved by Securitate, the flyers were mailed in late April 1948 to a small number of clerics, faithful Christians, ${ }^{14}$ and even Church officials such as Patriarch Justinian Marina, ${ }^{15}$ Metropolitan of Oltenia Nifon Criveanu, and Stanciu Stoian, the then Minister of Religious Denominations (Ministrul Cultelor) (Boila and Cretzianu 1956: 174). ${ }^{16}$ The manifesto urged people to not celebrate Labor Day but to maintain it as a day of fasting and prayer. ${ }^{17}$ This is because in that year May Day fell on the Saturday of the Christian Passion Week, the week before Easter, which, by 1948, was no longer permitted to be celebrated publicly (Deletant 1995: 11).

From Securitate documents accumulated about these flyers, Plamadeala was involved in neither their writing nor their distribution. His name appeared on the list of students accused of Legionarism, as Securitate documents confirm, because he was denounced as being a legionary by three students. Their names

\footnotetext{
${ }^{11}$ ACNSAS, fond penal, dossier 905, vol. 2: 2.

${ }^{12}$ Ibid.

${ }^{13}$ ACNSAS, fond penal, dossier 905, vol. 6: 151-156.

${ }^{14}$ ACNSAS, fond penal, dossier 905, vol. 6, 6: 27. The manifestos were delivered in envelopes, some of which were marked with a small sign, addressed to priests. ACNSAS, fond penal, dossier 905, vol. 6: 37.

${ }^{15}$ Justinian Marina (1901-1977) pursued his theological education in Bucharest, at the Faculty of Theology from 1925 to 1929. He then worked at the Theological Seminary in Ramnicul-Valcea, and later served as vicar bishop and metropolitan of Moldavia (eastern part of Romania). From 1948 to his death he served as the patriarch of the Romania Orthodox Church (Leustean 2009: 199).

${ }^{16}$ ACNSAS, fond penal, dossier 905, vol. 6: 94.

${ }^{17}$ ACNSAS, fond penal, dossier 905, vol. 6: 160.
} 
were: Vaman Constantin, ${ }^{18}$ Constantin Nistor and Ioan Pavel (Plamadeala and Petcu 2011: 50-51). Two of these students, however, changed their story in respect to Plamadeala when asked to testify in Court during his trial (1954-1956). For example, Vaman Constantin is cited as having confessed at the Pitesti prison to Roman Braga, one of the thirty arrested students and witness at Plamadeala's trial, ${ }^{19}$ that Constantin was "forced" (fortat) ${ }^{20}$ by those who interrogated him to identify Plamadeala as a legionary. ${ }^{21}$ Furthermore, in Vaman's statement provided during Plamadeala's trial session dating from 29 June 1955, Vaman claimed that "we did not have any member in the legionary nest with the name Plamadeala." ${ }^{22}$ Similarly, Ion Pavel in his declaration at Plamadeala's trial ${ }^{23}$ admitted that he knew Plamadeala by "name" but not by "face" (dupa figura) possibly implying that he maybe heard of his existence but never had personal contact with him. He also stated that, "at the interrogations [from 1948] I provided (aratat) more names due to pressures. In 1946-1947 I knew Plamadeala...only as a simple student." ${ }^{24}$ The "pressure" or "force" applied on these students during interrogations, as Ion Pavel and respectively Vaman Constantin suggested in their later declarations, may have most likely led to the creation of false declarations in respect to Plamadeala, the very declarations that served as basis for Securitate's building a case against in Plamadeala in 1949 and incriminating him for alleged ties to the Legion. ${ }^{25}$

While the inconsistencies pertaining to the case Securitate built against Plamadeala in 1949 may be singled out by comparing other Securitate documents, as it was discussed above, other errors and forgeries in Plamadeala's Securitate files can be identified by referring to sources outside the collection of Securitate documents on this theologian, as it is the case of the Securitate records presented below. The documents presented here illustrate that those who wrote

\footnotetext{
${ }^{18}$ ACNSAS, fond penal, dossier 905, vol. 1: 17.

${ }^{19}$ The document with Braga's full declaration is found at ACNSAS, fond penal, dossier 905, vol. 4: 69-70.

${ }^{20}$ ACNSAS, fond penal, dossier 905, vol. 4: 115.

${ }^{21}$ Ibid.

${ }^{22}$ ACNSAS, fond penal, dossier 905, vol. 4: 76.

${ }^{23}$ ACNSAS, fond penal, dossier 905, vol. 4: 75.

${ }^{24}$ Constantin Nistor, the other student who denounced Plamadeala as being a Legionary, was never able to take part at Plamadeala's trial to confirm whether his initial denunciations were true or fabricated. His death certificate confirms that he died from tuberculosis in 1950 at the Targul Ocna prison. ACNSAS, fond penal, dossier 905, vol. 4: 137.

${ }^{25}$ For a more detailed account on Plamadeala's retrial, see Plamadeala and Petcu 2011: 74-87.
} 
them distorted the truth, deliberately or not, for reasons, which are difficult to pinpoint with full certainty.

Photo 1 concerns a document wherein Plamadeala is listed (number 14) as a student in the faculty of medicine-a false statement, as Plamadeala never attended medical school. His education has always been in the realm of theology, with the exception of one year of studies in pedagogy in Chisinau, Bessarabia (Buda and Maica Anastasia 2012: 235-236), prior to his exile to Romania in 1944. In this document Plamadeala's first name is Leonida, his name prior to his becoming a monk in 1949.

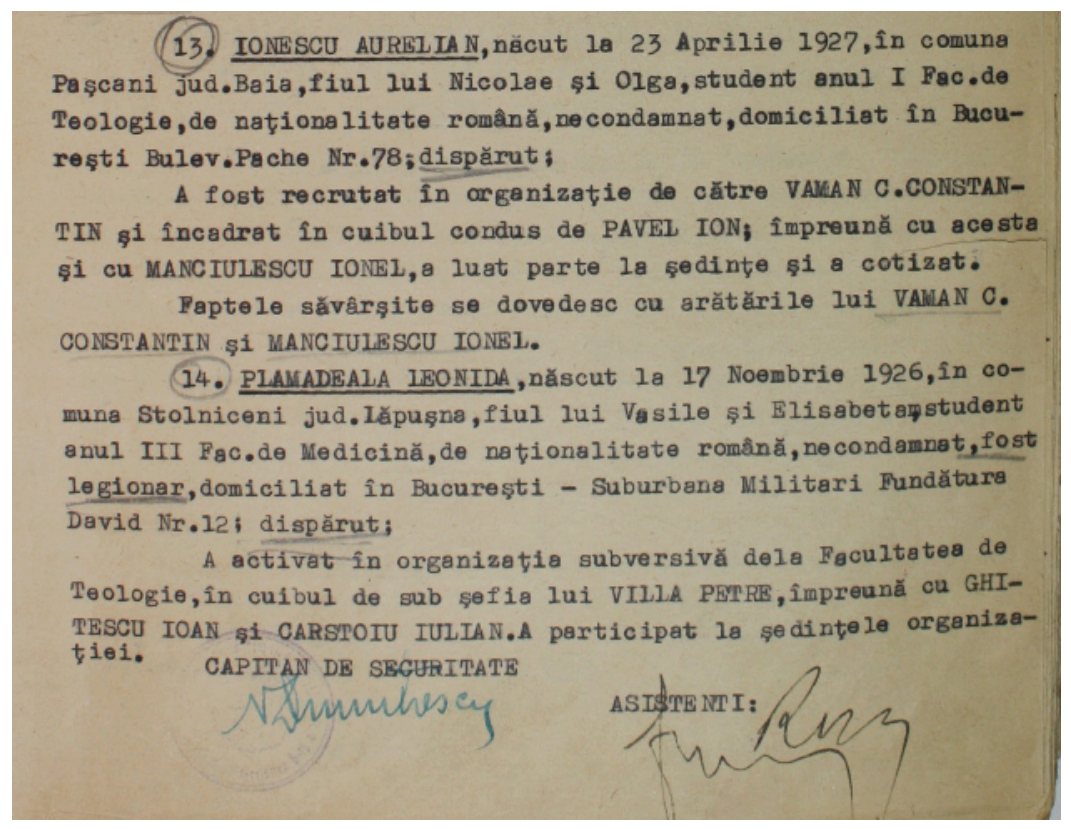

Photo 1: Plamadeala identified as a medical student.

ACNSAS, fond penal, dossier 905, vol. 1: 6.

Photo 2 features an actual declaration, falsified to seem that it was written and signed by Plamadeala. The theologian had a distinct writing and signature, which may be identified in Photo 3. As one can see in Photo 2, the person who wrote and signed as Plamadeala forged this document. Neither the writing style nor the signature are the same as in Photo 3. Photo 3 is a document found in Plamadeala's Securitate files, with writing style consistent with Plamadeala's, as 
shown on a cover of a book about Plamadeala. Photo 4 exhibits one of Plamadeala's hand written letters.

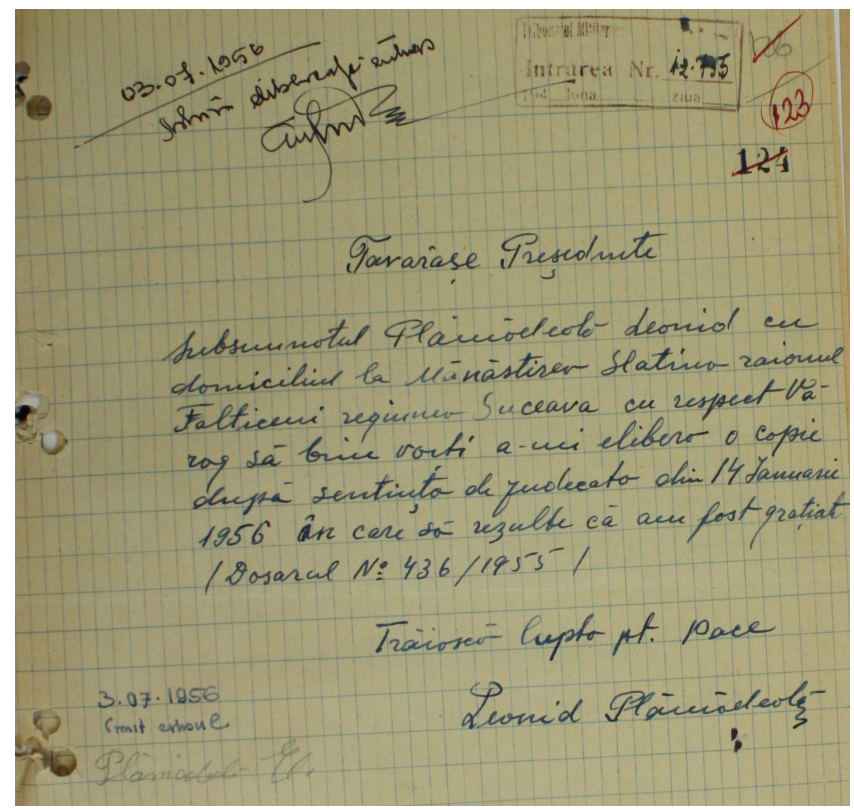

Photo 2: Plamadeala's forged writing and signature. ACNSAS, fond penal, dossier 905, vol. 3: 123.

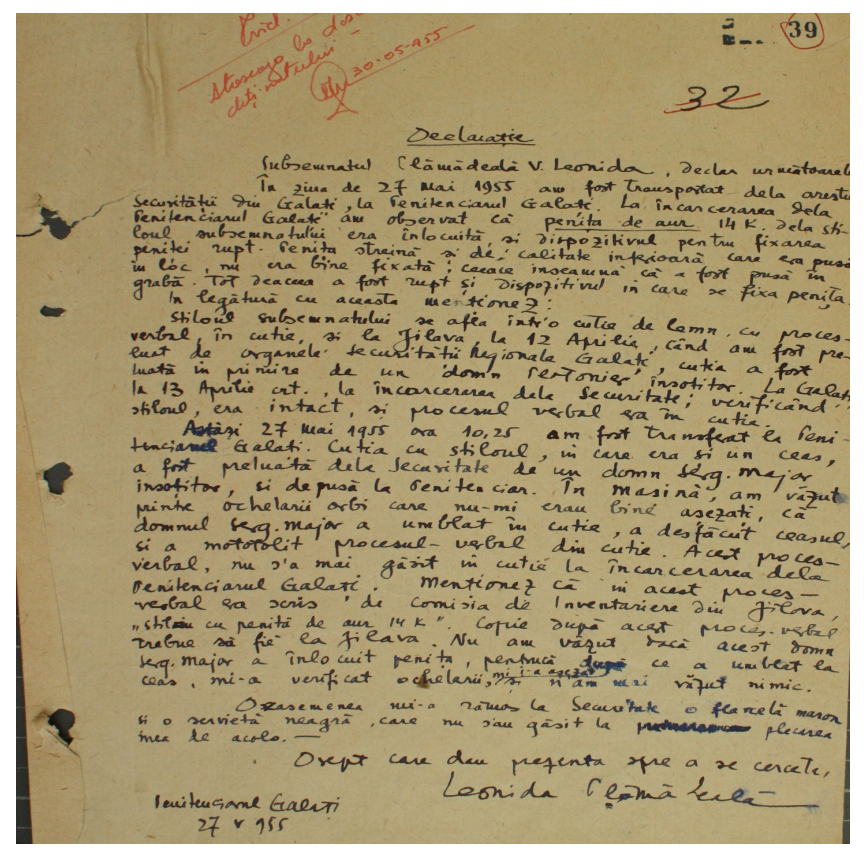

Photo 3: Plamadeala's writing and signature. ACNSAS, fond penal, dossier 905, vol. 8: 39. 


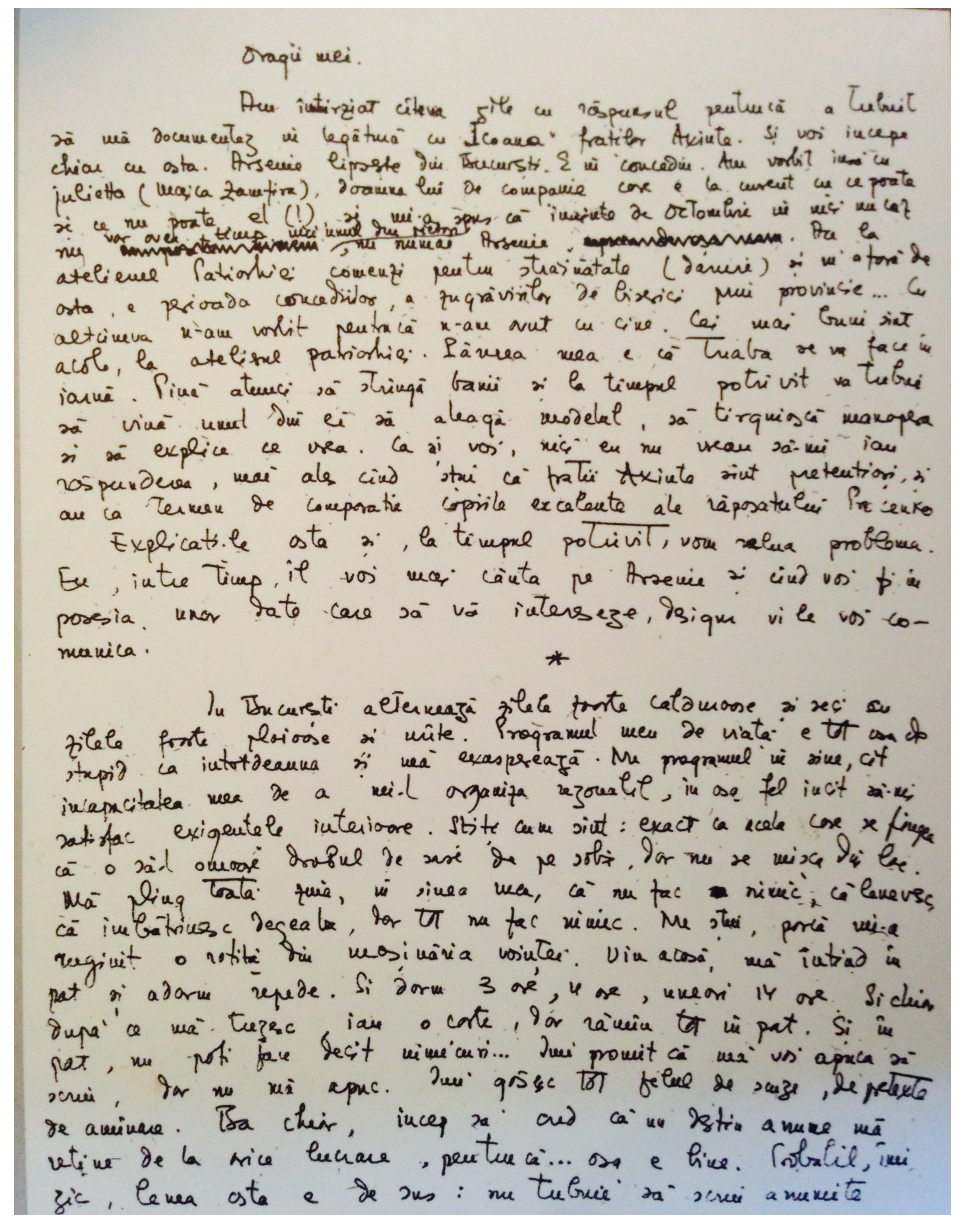

Photo 4: Antonie Plamadeala's handwriting, as seen in one of his letters.

Book cover of Timotei Aioanei (2013).

Photo 5 provides an example of forgery of Plamadeala's signature. Photo 3 features the actual signature of Plamadeala. 


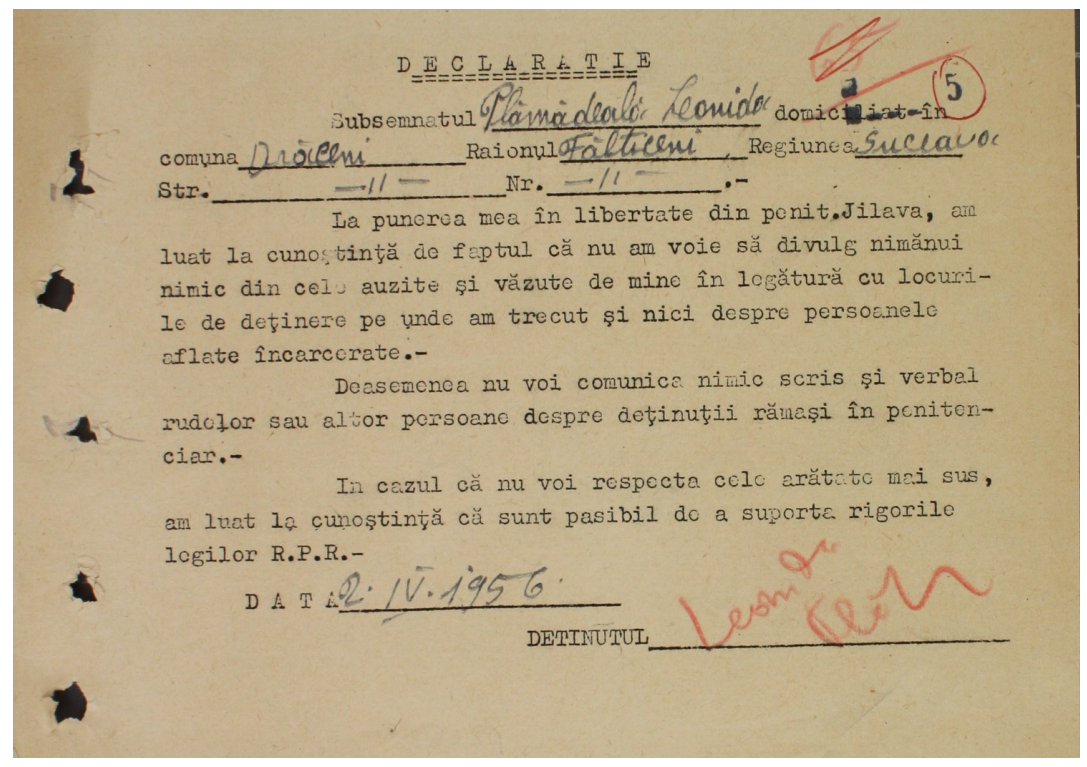

Photo 5: Plamadeala's forged signature.

ACNSAS, fond penal, dossier 905, vol. 8: 5.

\section{Using the Files to Reconstruct the "Truth"}

Essentially, the documents mentioned here give a glimpse of the Securitate personnel who wrote these files. The insight they give about these individuals calls into question their objectivity and truthfulness. As Cristina Vatulescu astutely put it, "sometimes wildly or craftily skewed records of historical fact, the files are at the same time priceless representations of the values, apprehensions, and fantasies entertained by the secret police" (2010: 13). These files' value lies in the insight they offer about the times in which they were produced and the political apparatus behind them. As far as the information they convey, reading these documents with the goal of understanding and deriving accurate conclusions entails, as Vatulescu argues, the need to "patiently re(learn) to read" (2010: 13), being attentive to inconsistencies to discern the truth from the falseness. In this context "(re)learning", I argue, entails embracing a skeptical and critical approach to the content they convey. One key task in reading secret police files is not only in identifying the truth but also in successfully pointing out the lies, errors and forgeries these files may contain.

Moreover, identifying the motives why a given lie or misleading information was written in a given document may prove useful in deciphering 
the veracity such a document may indeed conceal. That which may have been fabricated or forged may provide useful clues concerning the real story(ies) such files intended to bury. In the case of Plamadeala, the fabrication of evidence employed to issue his arrest order in 1949, evidence which was used in his 1949 trial, may suggest that Securitate was not necessarily after him for his alleged ties to the Legion but for something else, perceived equally threatening nonetheless to the newly established Communist regime in Romania.

In respect to Securitate's surveillance of civilians, Romanian writer Nicolae Steinhardt once wrote that "you are not accused for what you have done, but for who you were" (cited in Verdery 2010: 54) or, as Katherine Verdery put it, one was accused for "being a particular kind of person: an enemy" (2010: 54). Echoing Steinhardt's and Verdery's observations, it is possible that in the case of Plamadeala his character and presumed-by-Securitate potentiality to oppose the establishment of the Communist regime, embodied in his writing and distribution of the clandestine ultranationalist newspaper The Echo of Bessarabia and his involvement in the anti-communist resistance, may have served as key reasons behind the secret police's interest in arresting the young Plamadeala. This he himself insinuates in his memoirs (Plamadeala and Petcu 2011: 52) and monograph Basarabia (Plamadeala 2003: 30).

Plamadeala's involvement in the anti-communist resistance and the writing of The Echo of Bessarabia as a theology student may have justifiably linked him to ultra-nationalist ideology and agenda, but not necessarily to Legionarism, of which, according to the theologian, "all the clerics that were arrested were accused" (cited in Seuleanu et al. 1999: 143). Adherence to ultranationalist ideals was not always synonymous to Legionarism (Clark 2012: 108). For the sake of simplifying things and more easily identifying their enemies, the Romanian Communist Party leadership and the Securitate, however, may have operated under the assumption that it was, and, as a result, may have labeled many as legionaries based on this false premise. Plamadeala seems to have been one of these cases. 


\section{Conclusion}

The arguments brought here in respect to lack or reliability of secret police files to tell the truth should by no means discredit altogether their usage in deciphering the past, but only to remind one of the intricate, at times ambiguous and flawed, stories these files tell, and of the need to approach with them with much required diligence. A Romanian proverb claims that "that which is written in ink cannot be cut by a hatchet" (ce-i scris cu bardita nu tai cu penita), thus suggesting a certain unquestionable authority when it comes to officially written documents, something which, as this proverb seems to imply, should not be subject to doubt. This article proposes another angle through which one may examine Securitate files. In the case of Securitate documents on Plamadeala, at least the ones to which I was given access by ACNSAS, such files do tell stories, often incomplete ones, artfully intertwining truth and untruth, all to serve the interest not necessarily of the ones these stories are about, but of the ones who wrote them.

\section{Bibliography}

Aioanei, T. (2013). Mitropolitul Antonie Plamadeala si amintirea unei prietenii: scrisori inedite [Metropolitan Antonie Plamadeala and the Memory of a Friendship: Unpublished Letters]. Sibiu: Editura Adreiana.

Atkin, N., M. Biddis, and F. Tallett (2011). The Wiley-Blackwell Dictionary of Modern European History since 1789. Malden, MA: Wiley-Blackwell.

Boila, R., and A. Cretzianu (1956). Captive Rumania: A Decade of Soviet Rule. New York: Praeger.

Buda, N., and Maica [Nun] Anastasia (2012). Mitropolitul Antonie al Ardealului: Rugul Aprins Al Constiintei Neamului [Metropolitan Antonie of Ardeal: The Burning Bush of Our National Conscious]. Cluj Napoca: Casa Cartii de Stiinta.

Clark, R. (2012). "Nationalism and Orthodoxy: Nichifor Crainic and the Political Culture of the Extreme Right in 1930s Romania" in The Journal of Nationalism and Ethnicity, 40, (1): 107-126. 
Deletant, D. (1995). Ceausescu and the Securitate: Coercion and Dissent in Romania, 1965-1989. Armonk, NY: M. E. Sharpe.

Fischel, J. R. (1998). The Holocaust. Westport, CT: Greenwood Press.

Leustean, L. (2009). Orthodoxy and the Cold War. Religion and Political Power in Romania, 1947-65. New York: Palgrave Macmillan.

Plamadeala, M., and A. N. Petcu (2011). Mitropolit Antonie, Detalii Biografice, Partea I, "Dosarele Nu Stiu Tot" [Metropolitan Antonie, Biographical Details, Part 1, Files Do Not Know Everything], Sibiu: Editura Andreiana.

Plamadeala, A. (2003). Basarabia [Bessarabia], Sibiu: Tipographia Eparhiala Sibiu.

Seuleanu, D., C. D. Seuleanu and I. Duvlea (1999) (eds.). Amintirile Mitropolitului Antonie Plamadeala [Memoirs of the Metropolitan Antonie Plamadeala], Bucharest: Editura CUM.

Shapiro, P. A. (2007). "Faith, Murder, Resurrection, the Iron Guard and the Romanian Orthodox Church." In Antisemitism, Christian Ambivalence and the Holocaust, edited by K. P. Spicer. Bloomington, IN: Indiana University Press, p. 136-170.

Stan, L., and N. Nedelsky (2013). "Access to Secret Files." In Encyclopedia of Transitional Justice, edited by L. Stan and N. Nedelsky. New York: Cambridge University Press, 1: 1-5.

Stan, L. and L. Turcescu (2007) Religion and Politcs in Post-Communist Romania. New York: Oxford University Press.

Ursache, R. (2013). “Archival Records as Evidence." In Encyclopedia of Transitional Justice, edited by L. Stan and N. Nedelsky. New York: Cambridge University Press, 1: 112- 117.

Vatulescu, C. (2010) Police Aesthetics: Literature, Film \& the Secret Police in Soviet Times. Stanford: Stanford University Press.

Verdery, K. (2014). Secrets and Truths. Ethnography in the Archive of Romania's Secret Police. Budapest: Central European University Press. 